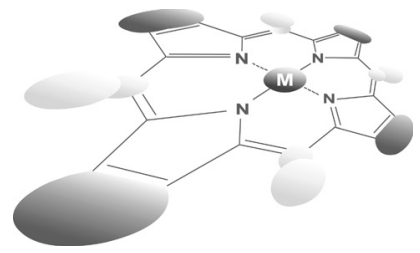

\title{
Investigation of solvation and solvent coordination effects in iron porphyrin nitrosyls by infrared spectroelectrochemistry and DFT calculations
}

\author{
Md. Hafizur Rahman and Michael D. Ryan* \\ Chemistry Department, P.O. Box 1881, Marquette University, Milwaukee, WI 53201, USA \\ Received 27 January 2019 \\ Accepted 26 February 2019
}

\begin{abstract}
Visible and infrared spectroelectrochemistry of Fe(OEPone)(NO) $\left(\mathrm{H}_{2} \mathrm{OEPone}=\right.$ octaethylporphinone) were examined in methylene chloride and THF. The visible spectra of $\mathrm{Fe}(\mathrm{OEP}$ ene)(NO) were similar in both solvents. Unlike other ferrous porphyrin nitrosyls, a six-coordinate complex was formed with THF as a ligand. This led to two nitrosyl bands in the infrared spectrum. The absorbance of these bands depended on the concentration of THF in the solution. Solvation and coordination effects on the carbonyl and nitrosyl bands were observed for both the nitrosyl and reduced-nitrosyl complexes. DFT calculations were carried out to interpret the spectral changes.
\end{abstract}

KEYWORDS: solvent coordination, iron porphyrin nitrosyl, infrared spectroelectrochemistry, DFT.

\section{INTRODUCTION}

Changes in the coordination geometry of ironporphyrin complexes can have a significant impact on their properties and reactivities. Iron porphyrin dioxygen and carbon monoxide complexes are typically six coordinate if ligands are present [1]. Ferrous nitrosyl porphyrins, however, are generally five-coordinate, even in the presence of ligands. Ligation of nitrosyl complexes generally weakens both the nitrosyl and the bond of the trans-ligand [2], often leading to dissociation of the NO and the formation of a bis-ligated complex [3-7]. In ferrous guanylate cyclase (sGC), the formation of a nitrosyl complex leads to the loss of histidine ligation and the formation of a 5-coordinate nitrosyl complex $[8,9]$.

\footnotetext{
${ }^{\diamond}$ SPP full member in good standing

*Correspondence to: Michael D. Ryan, Chemistry Department, P.O. Box 1881, Marquette University, Milwaukee, WI 53201, USA. Tel.: 1-414-288-1625, Fax: 1-414-288-7066, email: michael. ryan@marquette.edu.

This is an open access article published by World Scientific Publishing and distributed under the of the Creative Commons Attribution (CC BY) 4.0 License, which permits use, distribution and reproduction in any medium, provided the original author(s) and source are credited.
}

Yoshimura [10] examined the effect of solvation on the nitrosyl bond of the Fe(PPDME)(NO) complex (PPDME = protoporphyrin-dimethyl ester). The energy of the band varied over a narrow range for a variety of solvents between 1658 and $1684 \mathrm{~cm}^{-1}$, with the most significant shift only being observed for the strongest coordinating solvents such as acetonitrile $\left(1658 \mathrm{~cm}^{-1}\right)$ and DMSO $\left(1660 \mathrm{~cm}^{-1}\right)$. Only a small shift was observed between $\mathrm{CCl}_{4}\left(1684 \mathrm{~cm}^{-1}\right)$ [11] and THF $\left(1673 \mathrm{~cm}^{-1}\right)$. The shifts in the nitrosyl band in the solvents studied were ascribed to solvation rather than coordination effects. Amines such as pyridine did yield bands for the five- and six-coordinate complexes. Nitrosyl bands for the six-coordinate amine complexes were observed between 1618 and $1643 \mathrm{~cm}^{-1}$ [10]. Linear relationships were observed between the $\mathrm{pK}_{\mathrm{a}}$ of the base and the $v_{\mathrm{NO}}$ stretching frequencies, but different linear relationships were observed for imidazoles, pyridines and aliphatic amines. The largest shifts were observed for imidazole, with smaller shifts for pyridines, then aliphatic amines. The shifts varied from $30 \mathrm{~cm}^{-1}$ for 3 -chloropyridine $\left(\mathrm{pK}_{\mathrm{a}}=2.84\right)$ to $47 \mathrm{~cm}^{-1}$ for 4-methylimidazole $\left(\mathrm{pK}_{\mathrm{a}}=\right.$ 7.52) and 4-dimethylaminopyridine $\left(\mathrm{pK}_{\mathrm{a}}=9.70\right)$.

The visible spectra of iron porphyrin nitrosyl complexes in the presence of nitrogenase bases were studies by Yoshimura and Ozaki [6]. Wyllie et al. [12] examined the crystal structures of five- and six-coordinate 


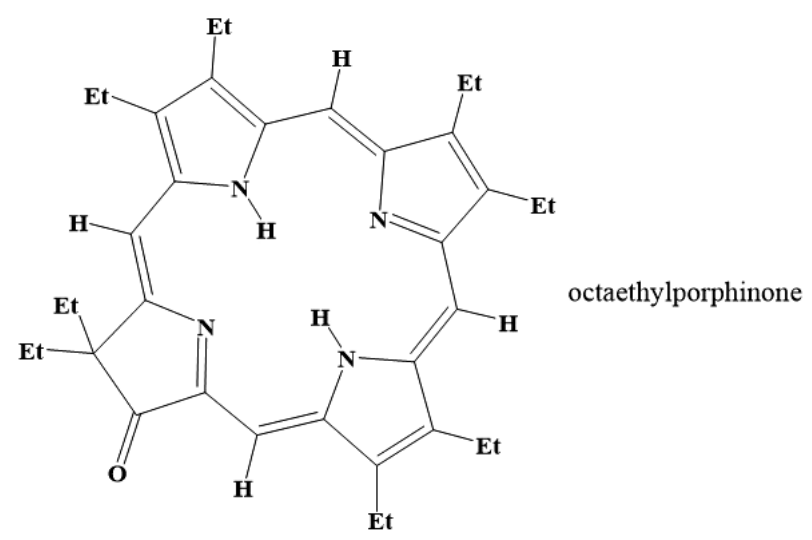

Fig. 1. Structure of octaethylporphinone

iron(II) porphyrin nitrosyls. Six-coordinate Fe(TPP)(NO) complexes with 1-methylimidazole or 4-methylpiperidine led to a lengthening and weakening the $\mathrm{Fe}-\mathrm{N}$ bond trans to the NO [3, 12-14]. In the six-coordinate complex, the spin density $(0.8)$ was mostly localized on the NO group, while there was a lower spin density $(0.5)$ for the five-coordinate complex [3]. The formation constants, $\mathrm{K}$, for pyridines and amines with iron porphyrin nitrosyls were determined using voltammetry by Choi and Ryan [4] and Liu et al. [15]. The K values were found to be generally small. The formation constants for $\mathrm{Fe}(\mathrm{OEP}$ one)(NO) and $\mathrm{Fe}(\mathrm{OEPdione})(\mathrm{NO})$ (OEPdione = 2,4-octaethylporphinedione) with pyridines were larger than $\mathrm{Fe}(\mathrm{OEP})(\mathrm{NO}) /$ pyridine complexes.

The infrared spectroelectrochemistry of $\mathrm{Fe}(\mathrm{P})(\mathrm{NO})$ complexes where $\mathrm{P}=$ porphyrins or porphinones has been examined in our laboratory, mostly in THF [16]. Upon further study, it was found that $\mathrm{Fe}(\mathrm{OEP}$ (n)e)(NO) $\left(\mathrm{H}_{2}\right.$ OEPone- $=$ octaethylporphinone, Fig. 1$)$ was more complex than reported with evidence of solvent (THF) coordination, that was not observed for $\mathrm{Fe}(\mathrm{OEP})(\mathrm{NO})$.

\section{EXPERIMENTAL}

\section{Materials and reagents}

Tetrahydrofuran (THF) and methylene chloride $\left(\mathrm{CH}_{2} \mathrm{Cl}_{2}\right)$ were purchased from Sigma-Aldrich Chemical Co. THF- $d_{8}$ and methylene chloride- $d_{2}$ were purchased from Cambridge Isotope Laboratories. The deuteriated solvents were used for infrared spectroelectrochemical experiments. Octaethylporphinone was purchased from Frontier Scientific, and iron was inserted and the nitrosyl complex synthesized by procedures in the literature $[17,18]$.

\section{Equipment and procedures}

The FTIR spectroelectrochemical cell was previously described [16]. The infrared spectra were obtained using 64 scans and $2 \mathrm{~cm}^{-1}$ resolution, recorded with a Thermo
Nicolet-FTIR spectrophotometer (Model 670 Nexus) with a MCT detector. The visible spectroelectrochemical experiments have been previously described [19]. UV-vis spectra were recorded on a HP 8452A diode array spectrophotometer. All solutions were prepared in a glove box under dinitrogen. For UV-vis spectra, a slow cyclic scan of the potential was used. For the FTIR, potentials were chosen to be sufficiently negative to insure complete electrolysis.

\section{Computational methods}

Electronic structure calculations were carried out with the Gaussian 09 suite of programs [20] using the procedures previously described [19], or, as noted, by the Gaussian 16 suite of programs [21]. Infrared frequencies were corrected with scale factors of 0.94 for m06, 0.96 for m06L and 1.0 for mpwvwn and bp86.

\section{RESULTS AND DISCUSSION}

\section{Infrared spectroscopy of $\mathrm{Fe}(\mathrm{OEP} P \mathrm{ne})(\mathrm{NO})$}

The infrared spectrum of $\mathrm{Fe}(\mathrm{OEPone})(\mathrm{NO})$ in methylene chloride was typical of other metalloporphyrin nitrosyls (Fig. 2). The $v_{\mathrm{NO}}$ bands in methylene chloride and $\mathrm{KBr}$ were identical (Table 1). Similar results were also observed for $\mathrm{Fe}(\mathrm{OEP})(\mathrm{NO})$. The downshift for ${ }^{15} \mathrm{NO}$ substitution for ${ }^{\text {na }} \mathrm{NO}$ (na = normal abundance) in methylene chloride was also consistent with metalloporphyrin nitrosyls. The infrared spectrum for $\mathrm{Fe}(\mathrm{OEP}$ one)(NO) in THF, however, was significantly different. The $v_{\mathrm{NO}}$ band at $1680 \mathrm{~cm}^{-1}$ was still observed in THF, but a new band was also seen at $1658 \mathrm{~cm}^{-1}$ (Fig. 2).

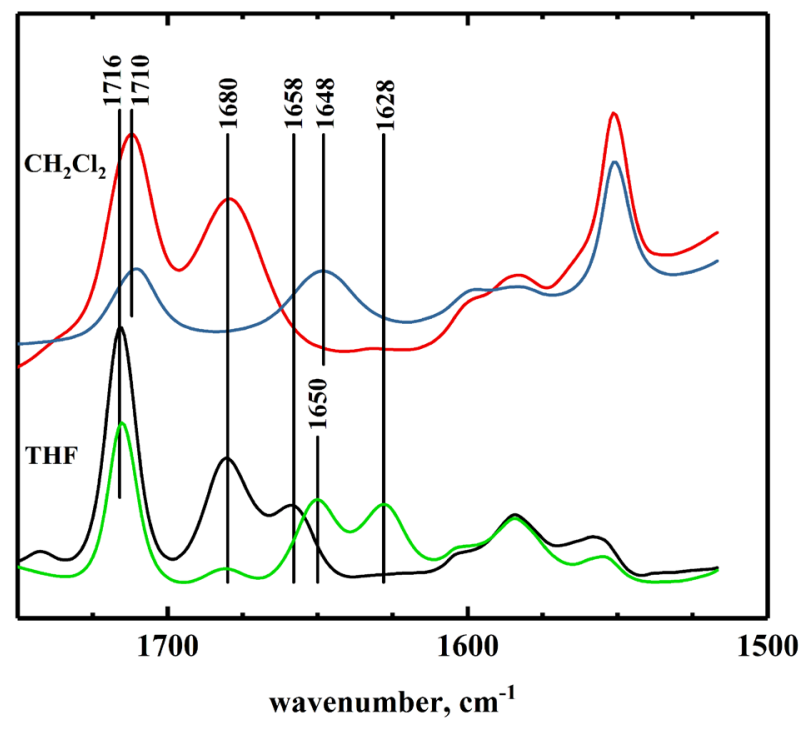

Fig. 2. Infrared spectra of $\mathrm{Fe}(\mathrm{OEPone})(\mathrm{NO})$ in methylene chloride and THF. $\mathrm{Fe}(\mathrm{OEPone})\left({ }^{\text {na }} \mathrm{NO}\right): \mathrm{CH}_{2} \mathrm{Cl}_{2}$ (red), THF (black); $\mathrm{Fe}\left(\mathrm{OEP} P\right.$ ene) $\left.{ }^{15} \mathrm{NO}\right): \mathrm{CH}_{2} \mathrm{Cl}_{2}$ (blue), THF (green) 
These bands have been previously observed, but the lower energy band was not attributed to be a nitrosyl vibration [16] because isotopic substitution was not done. In this work, it was found that both bands were sensitive to ${ }^{15} \mathrm{NO}$ substitution. The lower-energy nitrosyl band in THF was consistent with a six-coordinate iron porphyrin nitrosyl complex. For nitrogen ligands, two nitrosyl bands were observed in the infrared spectra of Fe(PPDME)(NO) in the presence of nitrogen ligands; the first was due to the 5-coordinate ferrous nitrosyl complex and the second (with a downshift of $33 \mathrm{~cm}^{-1}$ ) was due to the 6-coordinate complex. Ligation trans- to the nitrosyl ligand in iron porphyrin complexes is generally weak. For example, the equilibrium constant for the ligation of pyridine with $\mathrm{Fe}(\mathrm{OEP})(\mathrm{NO})$ is about 0.3 , which increased to 4.8 for $\mathrm{Fe}(\mathrm{OEPone})(\mathrm{NO})$ [15].

Repeating the experiment with $\mathrm{Fe}(\mathrm{OEP})(\mathrm{NO})$, only a single isotopically sensitive ${ }^{15} \mathrm{NO}$ band was observed in methylene chloride and THF. In addition, there was no significant difference in the $v_{\mathrm{NO}}$ band between $\mathrm{KBr}$ pellets and THF. The infrared bands for $v_{\mathrm{CO}}$ and $v_{\mathrm{NO}}$ are summarized in Table 1. In addition to the downshift of the nitrosyl band, the $v_{\mathrm{CO}}$ was upshifted by $5 \mathrm{~cm}^{-1}$ in THF as compared to methylene chloride. On the other hand, the $v_{\mathrm{NO}}$ was the same in methylene chloride and the fivecoordinate complex in THF $\left(1681 \mathrm{~cm}^{-1}\right)$ (Table 1$)$.

The appearance of the $1658 \mathrm{~cm}^{-1}$ band was found to be a function of the \% THF in methylene chloride (Fig. S1). The band could be clearly observed at $60 \%$ THF or more, and the height of the band, relative to the $1680 \mathrm{~cm}^{-1}$ band increased as the \% THF increased. A rough estimate of the percent 6-coordinate complex that was present was estimated by using the absorbance of the $v_{\mathrm{CO}}$ band as a reference and assuming that the molar absorptivities of the $v_{\mathrm{CO}}$ band of the 5- and 6-coordinates are the same. With these rough assumptions, $22 \%$ of the iron nitrosyl species was 6-coordinate in 60\% THF, increasing to $46 \%$ in pure THF. This would yield a $\mathrm{K}$ for the formation of the 6-coordinate THF complex to be $0.07 \pm 0.02$.

\section{Spectroelectrochemical reduction of $\mathrm{Fe}$ (OEPone) (NO) in methylene chloride and THF}

The visible spectroelectrochemistry of $\mathrm{Fe}(\mathrm{OEP}$ (One) (NO) in methylene chloride is shown in Fig. S2. The Soret band shifted from 406 to $410 \mathrm{~nm}$ and decreased slightly in absorbance. In the longer wavelength region, the $625 \mathrm{~nm}$ band disappeared and two new bands at 532 and $612 \mathrm{~nm}$ appeared. Similar results were observed for the reduction of $\mathrm{Fe}(\mathrm{OEPone})(\mathrm{NO})$ in THF (Fig. S3), with the Soret band shifting from 410 to $415 \mathrm{~nm}$. The $\mathrm{Q}$ band for the nitrosyl complex was $618 \mathrm{~nm}$, and for the reduced nitrosyl complex the bands were 535 and $607 \mathrm{~nm}$.

The infrared spectroelectrochemical difference spectra of $\mathrm{Fe}(\mathrm{OEPone})(\mathrm{NO})$ in methylene chloride is shown in Fig. 3. The general features show reduction of the carbonyl band at $1710 \mathrm{~cm}^{-1}$ and the nitrosyl band at $1681 \mathrm{~cm}^{-1}$. The reduced nitrosyl band at $1440 \mathrm{~cm}^{-1}$ increased as the reduction proceeded. The carbonyl band was considerably downshifted by the reduction, as can be seen by the positive $\Delta \mathrm{A}$ band at $1662 \mathrm{~cm}^{-1}$. The inset in Fig. 3 shows the absorbance spectra for $\mathrm{Fe}(\mathrm{OEP}$ (One)(NO) and $\mathrm{Fe}(\mathrm{OEP} o n e)(\mathrm{NO})^{-}$between 1750 and $1600 \mathrm{~cm}^{-1}$. The band at $1669 \mathrm{~cm}^{-1}$ for $v_{\mathrm{CO}}$ can be seen (the overlap with the nitrosyl band caused a shift in the difference spectrum). This downshift was comparable to the $v_{\mathrm{CO}}$ band shift that was observed for the formation of $\mathrm{Fe}\left(\mathrm{OEP}\right.$ (One) ${ }^{-}$in THF $\left(1671 \mathrm{~cm}^{-1}\right)$ [16]. The infrared spectroelectrochemistry of $\mathrm{Fe}(\mathrm{OEPone})\left({ }^{15} \mathrm{NO}\right)$ was carried out (Fig. S4). The nitrosyl band was downshifted to $1647 \mathrm{~cm}^{-1}$ and the reduced nitrosyl band to $1410 \mathrm{~cm}^{-1}$. These shifts were consistent with the isotopic substitution. As expected, the carbonyl

Table 1. Experimental and calculated infrared bands for $\mathrm{CO}$ and NO vibrations

\begin{tabular}{llccc}
\hline Compound & & Solvent & $\mathrm{v}_{\mathrm{CO}}, \mathrm{cm}^{-1}$ & $\mathrm{v}_{\mathrm{NO}}, \mathrm{cm}^{-1}$ \\
\hline $\mathrm{Fe}($ OEPone)(NO) & Experimental & $\mathrm{CH}_{2} \mathrm{Cl}_{2}$ & 1710 & 1681 \\
& Experimental & $\mathrm{THF}$ & 1715 & 1681 \\
& Experimental & $\mathrm{KBr}$ & 1715 & 1681 \\
& DFT/m06 & - & 1720 & 1683 \\
& DFT/m06L & - & 1718 & 1702 \\
& DFT/bp86 & - & 1701 & 1690 \\
$\mathrm{Fe}($ OEPone)(THF)(NO) & Experimental & $\mathrm{THF}$ & 1715 & 1658 \\
& DFT/m06 & - & 1721 & 1683 \\
& DFT/m06L & - & 1713 & 1694 \\
& DFT/bp86 & - & 1698 & 1672 \\
$\mathrm{Fe}($ OEPone $)(\mathrm{NO})^{-}$ & Experimental & $\mathrm{CH}_{2} \mathrm{Cl}_{2}$ & 1669 & 1440 \\
& Experimental & $\mathrm{THF}$ & 1702 & 1440 \\
& DFT/m06 & - & 1679 & 1538 \\
\hline
\end{tabular}




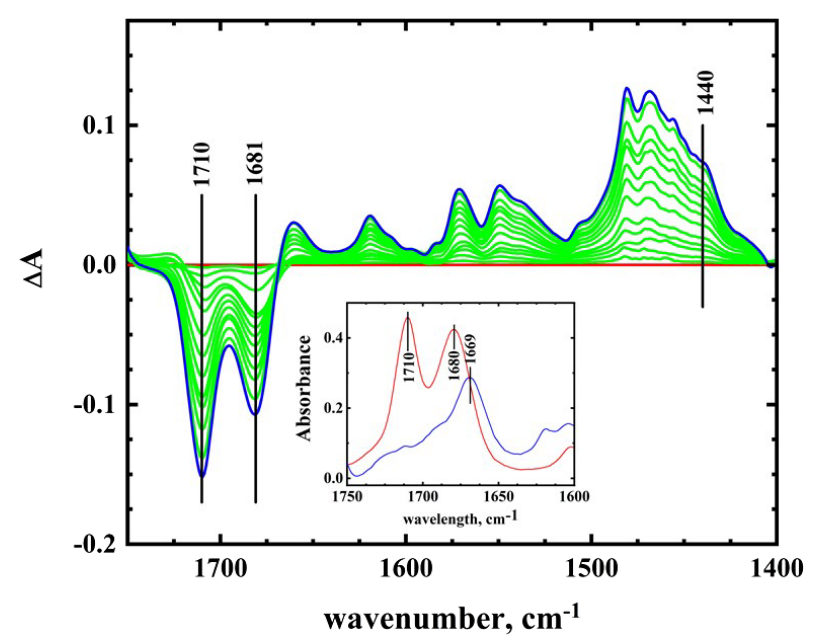

Fig. 3. Difference infrared spectroelectrochemical spectra of $\mathrm{Fe}(\mathrm{OEPone})(\mathrm{NO})$ in $\mathrm{CD}_{2} \mathrm{Cl}_{2}$. Red spectra: initial difference spectrum; green: intermediate spectra; blue: final spectrum. Inset: Absorbance spectrum of $\mathrm{Fe}(\mathrm{OEPone})(\mathrm{NO})$ (red); spectrum of $\mathrm{Fe}(\mathrm{OEP}$ one)(NO) (blue)

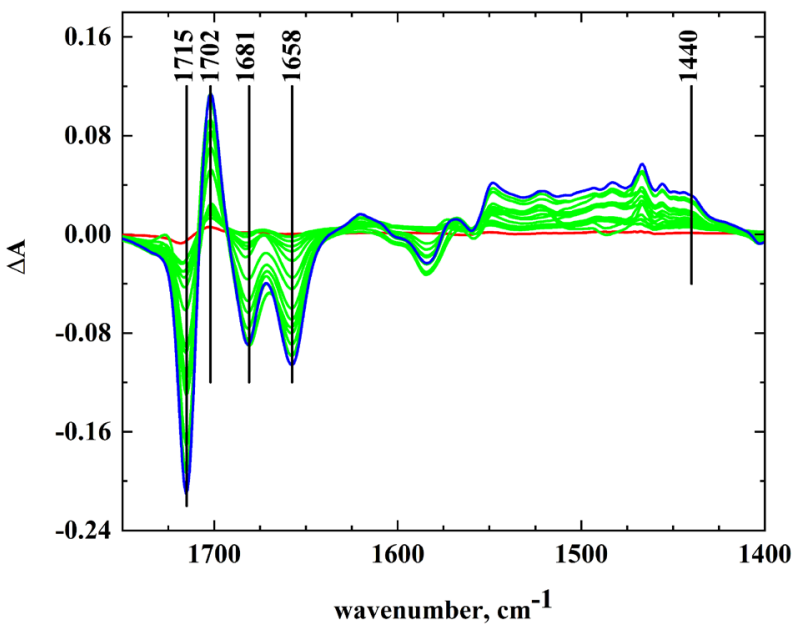

Fig. 4. Difference infrared spectroelectrochemical spectra of $\mathrm{Fe}(\mathrm{OEPone})(\mathrm{NO})$ in THF. Red spectra: initial difference spectrum; green: intermediate spectra; blue: final spectrum

bands for the nitrosyl and the reduced nitrosyl complexes were unchanged from the normal abundance spectra.

The infrared spectroelectrochemistry of $\mathrm{Fe}$ (OEPone) (NO) in THF is shown in Fig. 4. Both Fe-NO bands decreased as the reduction proceeded, but only one $v_{\mathrm{NO}}\left(1440 \mathrm{~cm}^{-1}\right)$ was observed for the reduced nitrosyl product, which was a value typical of other reduced ferrous porphyrin nitrosyls [16], and $\mathrm{Fe}$ (OEPone) (NO) in methylene chloride. The downshift of the $v_{\mathrm{CO}}$ band is significantly smaller (1715 to $1702 \mathrm{~cm}^{-1}$ ) than the shift observed earlier in methylene chloride. The results were confirmed for $\mathrm{Fe}\left(\mathrm{OEP}\right.$ (One) $\left({ }^{15} \mathrm{NO}\right)$ (Fig. S5) where the nitrosyl and the reduced nitrosyl bands were both downshifted as expected, and the carbonyl bands were at the same position as for the normal abundance spectra. The small shift in the $v_{\mathrm{CO}}$ band as compared to methylene chloride was probably due to solvation rather than coordination effects. This will be investigated in the next section. Voltammetric data showed no evidence for 6-coordinate complexes for the reduced nitrosyl complex, consistent with the fact that stronger ligands showed no evidence of coordination $[4,15]$.

\section{DFT calculations}

DFT calculations were carried out on the 5- and 6-coordinate $\mathrm{Fe}(\mathrm{OEPone})(\mathrm{NO})$ complexes and their reduction product. In general, the localized functionals such as m06L and bp86 predicted stronger Fe-THF interactions than $\mathrm{m} 06$ and mpwvwn. In fact, mpwvwn predicted no bond between iron and THF. For the other functionals, the $\mathrm{Fe}-\mathrm{O}$ (THF) bond lengths from $2.489 \AA$ (bp86) to $2.569 \AA$ (m06) were calculated. These bond lengths were somewhat longer than the experimental $\mathrm{Fe}-\mathrm{O}$ (THF) bond length in $\mathrm{Fe}(\mathrm{TPP})(\mathrm{THF})_{2}$ of $2.351 \AA$ [22]. The calculated $\mathrm{O}-\mathrm{Fe}-\mathrm{N}$ bond angle in $\mathrm{Fe}$ (OEPone) (THF)(NO) was found to be $173^{\circ}$, with the deviation due to the known tilt of the Fe-NO group. The DFT calculations were consistent with a weak complexation of THF to the iron-nitrosyl complex.

The calculated $v_{\mathrm{NO}}$ and $v_{\mathrm{CO}}$ bands for $\mathrm{Fe}($ OEPone) (NO) complexes are shown in Table 1. The m06 functional predicted the longest $\mathrm{Fe}-\mathrm{O}$ (THF) bond and also predicted that THF coordination would not affect the $v_{\mathrm{NO}}$ and $v_{\mathrm{CO}}$ bands. As would be expected, a shorter $\mathrm{Fe}-\mathrm{O}(\mathrm{THF})$ bond led to a greater downshift in the $v_{\mathrm{NO}}$ band, dropping by $8 \mathrm{~cm}^{-1}$ for m06L to $18 \mathrm{~cm}^{-1}$ for bp86. These compare with the observed downshift of $23 \mathrm{~cm}^{-1}$. The absolute values of the $v_{\mathrm{NO}}$ and $v_{\mathrm{CO}}$ energies followed trends which we have seen earlier. The bp86 functional predicts reasonably well the experimental values without a scale factor, but its energies are systematically low [23]. The m06 and m06L generally need a scale factor of 0.94 and 0.96 , respectively, for these complexes. In this work, the bp86 predicted a small upshift in the $v_{\mathrm{CO}}$ band upon forming the THF complex (as was observed), while the m06 functional showed no shift and the m06 functional predicted a downshift.

As was discussed earlier [3], the SOMO for $\mathrm{Fe}(\mathrm{OEPone})(\mathrm{NO})(\mathrm{THF})$ is mostly localized on the $\mathrm{Fe}-\mathrm{NO}$ moiety (Fig. S6). By contrast, there was significant delocalization of the electron density in the five coordinate complex (Fig. S6). Similar results were observed by Praneeth et al. [3] for $\mathrm{Fe}(\mathrm{P})(\mathrm{NO})$ complexes with nitrogen ligands.

DFT calculations of $\mathrm{Fe}(\mathrm{OEP}$ (Ne)(NO)(THF)- showed a much weaker interaction between the $\mathrm{Fe}$ atom and THF than was observed for the nitrosyl complex. The $\mathrm{Fe}-\mathrm{O}$ (THF) bond length increased from $2.530 \AA$ to $2.657 \AA$ (m06L), with an O-Fe-N bond angle of $176^{\circ}$. As discussed earlier, stronger ligands such as pyridine showed no evidence for coordination with the reduced 


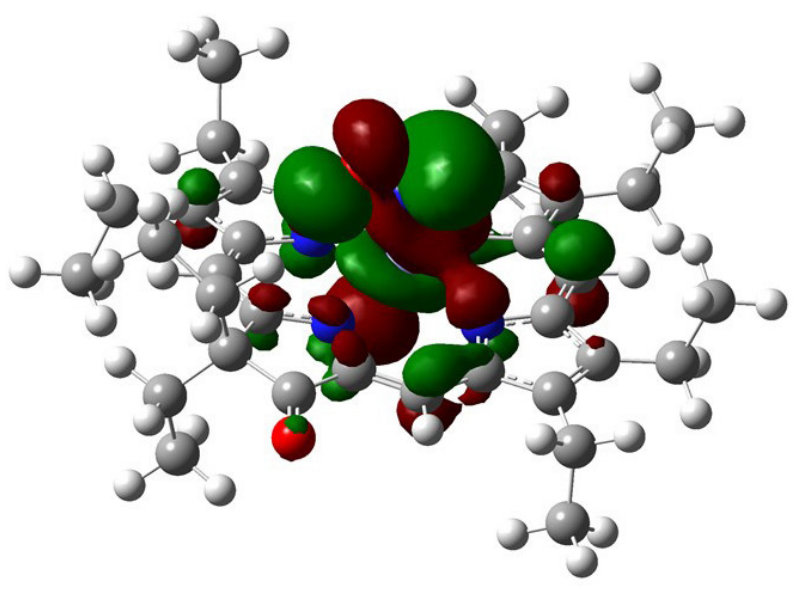

(a)

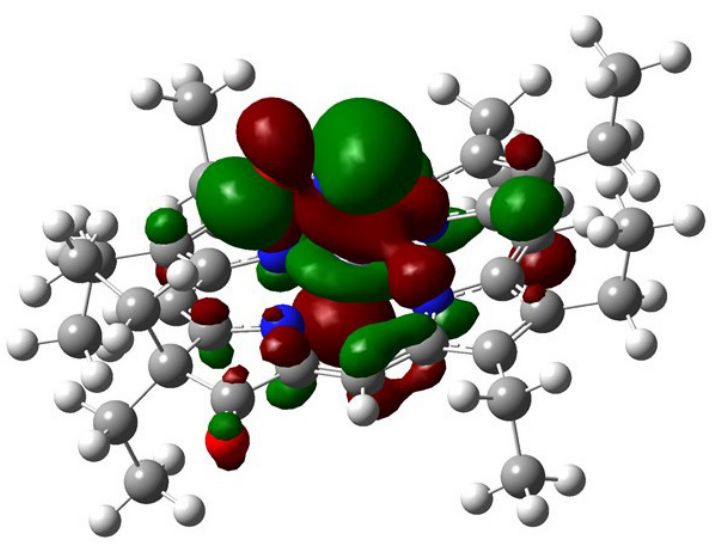

(b)

Fig. 5. HOMO orbitals for $\mathrm{Fe}(\mathrm{OEPone})(\mathrm{NO})^{-}$with $\mathrm{THF}$ solvation (a) and without solvation (b). Functional: m06. Gaussian 16

nitrosyl complex. Thus, both DFT calculations and experimental evidence showed that the reduced iron nitrosyl species was 5-coordinate. The most significant difference in the infrared specta between $\mathrm{Fe}$ (OEPone) (NO) ${ }^{-}$in THF and methylene chloride is the carbonyl band. Only a small downshift was observed for $v_{\mathrm{CO}}$ in THF solution (1715 to $1702 \mathrm{~cm}^{-1}$, or $13 \mathrm{~cm}^{-1}$ downshift), while the $v_{\mathrm{CO}}$ in methylene chloride decreased from 1710 to $1669 \mathrm{~cm}^{-1}$ (41 cm $\mathrm{cm}^{-1}$ downshift). The origin of this shift is not due to coordination differences, but rather due to solvation. Evidence for this can be seen in comparing the HOMO for $\mathrm{Fe}(\mathrm{OEPone})(\mathrm{NO})^{-}$with and without solvation (Fig. 5). Figure 5a shows the HOMO for THF-solvated $\mathrm{Fe}(\mathrm{OEP}$ one)(NO). The electron density was mostly on the Fe-NO moiety, with essentially no electron density on the carbonyl group. By contrast, Fig. 5b (for the unsolvated complex) showed an increased electron density on the carbonyl group, in an anti-bonding $\pi^{*}$ orbital, weakening the $\mathrm{C}-\mathrm{O}$ bond, consistent with a larger downshift in the poorly solvating methylene chloride. This has been observed before for Ni(OEPone) ${ }^{-}$where interactions between a strongly associated cation and the carbonyl group [24] downshifted the $v_{\mathrm{CO}}$ band by increasing the electron density on the carbonyl group, and hence, the $\pi^{*}$ orbital. The observed differences in the $v_{\mathrm{CO}}$ between the two solvents can be best attributed to solvation rather than iron coordination effects.

\section{CONCLUSIONS}

Solvents can affect the spectral and redox properties of a complex by either solvation or coordination effects. Ferrous porphyrin nitrosyl complexes are often 5-coordinate, and 6-coordinate complexes are prone to the loss of NO and the formation of bis-ligand complexes. While $\mathrm{Fe}(\mathrm{OEP})(\mathrm{NO})$ shows no evidence of coordination with THF, the porphinone analogue was able to form a 6-coordinate complex with THF. In this work, the combination of infrared spectroelectrochemistry and DFT calculations made it possible to identify changes that were primarily due to coordination or solvation. Solvent coordination by THF to the ferrous nitrosyl complex was the source of the significant downshift in the $v_{\mathrm{NO}}$ band for $\mathrm{Fe}(\mathrm{OEPone})(\mathrm{NO})$. For $\mathrm{Fe}(\mathrm{OEP}$ one)(NO), solvation was the source of the observed changes in the carbonyl band, with little evidence for the formation of a sixcoordinate complex. This was consistent with previous studies where the reduced iron-nitrosyl complex was a much weaker Lewis acid. On the other hand, the solvation of the reduced Fe-nitrosyl moiety by THF drew electron density away from the $\pi^{*}$ orbital between $\mathrm{C}$ and $\mathrm{O}$, causing the $\mathrm{v}_{\mathrm{CO}}$ to downshift significantly less than was observed in a non-coordinating solvent such as methylene chloride.

\section{Supporting information}

Figures S1-S6 are given in the supplementary material. This material is available free of charge via the Internet at http://www.worldscinet.com/jpp/jpp.shtml.

\section{REFERENCES}

1. Linder DP, Silvernail NJ, Barabanschikov A, Zhao J, Alp EE, Sturhahn W, Sage JT, Scheidt WR and Rodgers KR. J. Am. Chem. Soc. 2014; 136: 9818-9821.

2. Komatsu T, Matsukawa Y and Tsuchida E. Chem. Lett. 2000: 1060-1061.

3. Praneeth VKK, Näther C, Peters G and Lehnert N. Inorg. Chem. 2006; 45: 2795-2811.

4. Choi I-K and Ryan MD. Inorg. Chim. Acta 1988; 153: 25-30.

5. Lançon D and Kadish KM. J. Am. Chem. Soc. 1983; 105: 5610-5617.

6. Yoshimura T and Ozaki T. Arch. Biochem. Biophys. 1984; 229: 126-135. 
7. Bohle DS and Hung CH. J. Am. Chem. Soc. 1995; 117: 9584-9585.

8. Stone JR and Marletta MA. Biochemistry 1994; 33 : 5636-5640.

9. Hunt AP and Lehnert N. Acc. Chem. Res. 2015; 48: 2117-2125.

10. Yoshimura T. Arch. Biochem. Biophys. 1983; 220: 167-178.

11. Yoshimura T. Bull. Chem. Soc. Jpn. 1978; 51: 1237-1238.

12. Wyllie GRA, Schulz CE and Scheidt WR. Inorg. Chem. 2003; 42: 5722-5734.

13. Scheidt WR and Piciulo PL. J. Am. Chem. Soc. 1976; 98: 1913-1919.

14. Scheidt WR, Brinegar AC, Ferro EB and Kirner JF. J. Am. Chem. Soc. 1977; 99: 7315-7322.

15. Liu YM, DeSilva $\mathrm{C}$ and Ryan MD. Inorg. Chim. Acta 1997; 258: 247-255.

16. Wei Z and Ryan MD. Inorg. Chem. 2010; 49: 6948-6954.

17. Stolzenberg AM, Strauss SH and Holm RH. J. Am. Chem. Soc. 1981; 103: 4763-4778.

18. Choi I-K, Liu YM, Wei Z and Ryan MD. Inorg. Chem. 1997; 36: 3113-3118.

19. Rahman MH and Ryan MD. Eur. J. Inorg. Chem. 2018: 1762-1765.

20. Frisch MJ, Trucks GW, Schlegel HB, Scuseria GE, Robb MA, Cheeseman JR, Scalmani G, Barone B, Mennucci B, Petersson GA, Natatsuji H, Caricota M, Li X, Hratchian HP, Izmaylov AF, Bloino J, Zheng G, Sonnenberg JL, Hada M, Toyota K, Fukuda R, Hasegawa J, Ishida M, Nakajima T, Honda Y, Kitao O, Nakai H, Vreven T, Montgomery JA, Jr., Peralta JE, Ogliaro F, Bearpark M, Heyd JJ, Brothers E, Kudin KN, Staroverov VN, Kobayashi R, Normand J, Raghavachari K, Rendell A, Burant
JC, Iyengar SS, Tomasi J, Cossi M, Rega N, Millam NJ, Klene M, Knox JE, Cross JB, Bakken V, Adamo C, Jaramillo J, Gomperts R, Stratmann RE, Yazyev O, Austin AJ, Cammi R, Pomelli C, Ochterski JW, Martin RL, Morokuma K, Zakrzewski VG, Voth GA, Salvador P, Dannenberg JJ, Dapprich S, Daniels AD, Farkas Ö, Foresman JB, Ortiz JV, Cioslowski J and Fox DJ; Gaussian 9. Gaussian, Inc.: Wallingford,CT, 2009.

21. Frisch MJ, Trucks GW, Schlegel HB, Scuseria GE, Robb MA, Cheeseman JR, Scalmani G, Barone V, Petersson GA, Nakatsuji H, Li X, Caricato M, Marenich AV, Bloino J, Janesko BG, Gomperts R, Mennucci B, Hratchian HP, Ortiz JV, Izmaylov AF, Sonnenberg JL, Williams, Ding F, Lipparini F, Egidi F, Goings J, Peng B, Petrone A, Henderson T, Ranasinghe D, Zakrzewski VG, Gao J, Rega N, Zheng G, Liang W, Hada M, Ehara M, Toyota K, Fukuda R, Hasegawa J, Ishida M, Nakajima T, Honda Y, Kitao O, Nakai H, Vreven T, Throssell K, Montgomery Jr. JA, Peralta JE, Ogliaro F, Bearpark MJ, Heyd JJ, Brothers EN, Kudin KN, Staroverov VN, Keith TA, Kobayashi R, Normand J, Raghavachari K, Rendell AP, Burant JC, Iyengar SS, Tomasi J, Cossi M, Millam JM, Klene M, Adamo C, Cammi R, Ochterski JW, Martin RL, Morokuma K, Farkas O, Foresman JB and Fox DJ: Gaussian 16, Gaussian, Inc.:Wallingford, CT, 2016.

22. Reed CA, Mashiko T, Scheidt WR, Spartalian K and Lang G. J. Am. Chem. Soc. 1980; 102: 2302-2306.

23. Tutunea F, Atifi A and Ryan MD. J. Electroanal. Chem. 2015; 744: 17-24.

24. Atifi A and Ryan MD. Anal. Chem. 2015; 87: 12245-12253. 